\title{
In vitro multiple shoot regeneration from corm bud explant in ghet kachu, typhonium trilobatum schott - a medicinal aroid
}

\author{
K. K. Paul and M. A. Bari \\ Institute of Biological Sciences, Rajshahi University, Rajshahi-6205, Bangladesh
}

\begin{abstract}
An efficient in vitro regeneration protocol was developed in medicinal aroid, Ghetkachu (Typhonium trilobatum Schott) using field grown corm bud explant. Highest percentage $(75 \%)$ of direct multiple shoot regeneration obtained in MS media supplemented with 5.0 mgL ${ }^{-1} \mathrm{BAP}$ $+1.5 \mathrm{mg} \mathrm{L}^{-1} \mathrm{NAA}$. Callus formation occur $(80 \%)$ in MS media containing $0.5 \mathrm{mgL}^{-1} \mathrm{BAP}+2.0 \mathrm{mgL}^{-1} \mathrm{NAA}$. The appearance of calli was white, creamy white light green in colour and the texture of calli were soft, friable and semi hard and compact. Shoot regeneration $(85 \%)$ obtained from calli in MS medium having $5.0 \mathrm{mgL}^{-1} \mathrm{BAP}+1.0 \mathrm{mgL}^{-1} \mathrm{NAA}$. The regenerated plantlets were successfully acclimatized with loamy fertile soil and survived cent percentage in natural condition.
\end{abstract}

Key words: Araceae, Ghetkachu, Phytohormone, Regeneration and Typhonium trilobatum

Abreviation: BAP (6-Benzyle Aminopurine), NAA ( $\alpha$-Napthalene acetic acid), IAA (Indole-3 Acetic Acid), IBA (Indole 3-butyric acid) and MS (Murashige and Skoog).

\section{Introduction}

The genus Typhonium is comprises of about 40 species of perennial, tuberous, soft succulent marshy, endanger plant with hastately 3-lobed leaves, and an extremely acrid tuberous root grows in damp and moist places in Chittagong and Sylhet and also in other parts of Bangladesh under Araceae family. It was distributed widely in tropical and subtropical Asia, Australia and Pacific islands of North Africa (Wang and Yang, 1996). This plant also distributed in South and central Malesia but reaching South India and Srilanka introduced into northeast India, East Africa, East Malaysia (Hay,1993). Four common species namely T blume, $T$ trilobatum, $T$ roxbergii and $T$ flagelliforme were critically studied as medicinal aroid by Nicolson and Sivadasan (1981). Hay, 1993; Hettercheid et al, 2000; Hettercheid et al, 2001; Sookchaloem, 1995 and Sriboonma, et al.1994 assumed that Typhonium is a "natural" (monophyletic) genus, derived in all its species-richness from one common ancestral species. The tender leaves with petiole of this plant used as vegetables. In Bangladesh the tribal people used this plant for treatment of involuntary discharges of semen, inflammation of testicles, cure for eruptions on face and nose, well dried tuber powder used for killing the mad dogs and jackals as poison. Acrid tubers and roots are stimulant, used for piles and as poultice to tumours, eaten with bananas to cure stom- ach complaints and applied externally to the bite of venomous snakes (Ghani,1998; Kritikar and Basu, 1914). Medicinal plants are rich sources of bioactive compounds. Serious efforts should be made to derive maximum economic benefit and save much needed foreign exchange from indigenous medicinal plants by using them as raw materials for the drug manufacturing industries. Tubers and roots contain a volatile acrid principle, $\beta$-sitosterol, two unidentified sterols (sterol A and sterol B) and a crystalline compound (Ghani, 1998; Vattarchya, 1405 Beng.). Pharmaceutical companies occurring stands which are being depleted rapidly, raising concern about possible extinction of the species and providing justification for the exploitation of in vitro propagation techniques for this medicinal plant. Tissue culture techniques helps in assessing and exploiting the genetic variability (Whitkus et al., 1994). Through tissue culture technique Typhonium species would be useful for the development of strategies for ex situ conservation of plant genetic resources. This in vitro techniques may help in the conservation of the species and possibly lead to the synthesis and extraction of active compounds from callus and rhizome sources.

*Corresponding author. E-mail: krshnnd@yahoo.com and barimiahbd@yahoo.com 


\section{Materials and Methods}

The plants were collected from Charghat upozilla, Rajshahi District and maintained in the experimental farm of Institute of Biological Sciences, Rajshahi University, Rajshahi on pot and field culture. Young plantlets were collected from that experimental farm and cut the leaves with petiole then they were washed with continuous tap water for cleaning the debris and soil. Then the shoot tubers were made into small pieces with lived shoot. The small corms were washed with tweeen - 80 and few drops of Savlon for sterilizing from external microorganisms with several times. Before culturing the corm buds as explant were dipped into $0.15 \% \mathrm{HgCl}_{2}$ for 20 minutes avoiding for surface sterilization. After 20 minutes they were washed with double sterilized water for 5 times and transferred into the culture bottle vessels through dressing. The cultural medium used throughout the experiments consisted of MS (Murashige and Skoog, 1962) medium, $3 \%(\mathrm{w} / \mathrm{v})$ sucrose, $0.8 \%(\mathrm{w} / \mathrm{v})$ Agar. The $\mathrm{pH}$ of all media were adjusted to $5.80 \pm 1$ before autoclaving. $30 \mathrm{ml}$ of medium dispersed into each glass vessel. After autoclav- ing $\left(121^{\circ} \mathrm{C}\right.$ and $\left.1.1 \mathrm{~kg} / \mathrm{cm}^{2}\right)$ for 30 minutes and removing the glass vessels from autoclave they were kept under cool condition. Prepared explants were inserted into the gelled media in a airflow cabinet with all arrangements. Cultured vessels were kept under 16 hours light and 8 hours darkness with the temperature maintained $25 \pm 1{ }^{\circ} \mathrm{C}$.

\section{Results and Discussion}

Experiments were conducted to investigate direct shoot regeneration, callus induction, indirect shoot regeneration and ability of corm bud explants excised of in vivo grown ghet kachu (Typhonium trilobatum Schott).

\section{Direct multiple shoot regeneration}

For differentiation of multiple shoots the explants were implanted horizontally on MS media supplemented with different concentrations and combinations of BAP and NAA. Results obtained on morphogenic response of the explants were found to vary with hormonal formulations present in the culture media. Highest percentage $(75 \%)$ of multiple

Table I: Effect of different concentration of phyto hormones on direct multiple shoot proliferation from corm bud explants of Ghet kachu (Typhonium trilobatum Schott)

\begin{tabular}{lcccc}
\hline $\begin{array}{l}\text { Growth regulator } \\
\text { mg/lBAP+NAA }\end{array}$ & $\begin{array}{c}\text { Days to shoot } \\
\text { proliferation }\end{array}$ & $\begin{array}{c}\text { \% of shoot } \\
\text { forming from explant }\end{array}$ & Mean \pm S.E & Mean \pm S.E \\
\cline { 3 - 4 } $3.0+0.5$ & $20-25$ & 45.00 & $4.00 \pm 0.316$ & $4.00 \pm 0.316$ \\
$3.0+1.0$ & $20-25$ & 45.00 & $5.00 \pm 0.273$ & $3.00 \pm 0.273$ \\
$3.0+1.5$ & $20-25$ & 60.00 & $4.00 \pm 0.316$ & $3.00 \pm 0.273$ \\
$3.0+2.0$ & $20-25$ & 45.00 & $3.00 \pm 0.273$ & $2.50 \pm 0.220$ \\
$3.0+2.5$ & $20-25$ & 40.00 & $3.00 \pm 0.273$ & $2.00 \pm 0.316$ \\
$4.0+0.5$ & $20-25$ & 36.00 & $3.00 \pm 0.273$ & $2.50 \pm 0.220$ \\
$4.0+1.0$ & $20-25$ & 45.00 & $4.00 \pm 0.316$ & $3.00 \pm 0.273$ \\
$4.0+1.5$ & $20-25$ & 50.00 & $3.00 \pm 0.273$ & $3.50 \pm 0.223$ \\
$4.0+2.0$ & $20-25$ & 40.00 & $2.00 \pm 0.316$ & $3.00 \pm 0.273$ \\
$4.0+2.5$ & $20-25$ & 30.00 & $4.00 \pm 0.316$ & $4.50 \pm 0.316$ \\
$5.0+0.5$ & $20-25$ & 45.00 & $5.00 \pm 0.273$ & $4.50 \pm 0.316$ \\
$5.0+1.0$ & $20-25$ & 60.00 & $4.00 \pm 0.316$ & $4.00 \pm 0.316$ \\
$5.0+1.5$ & $20-25$ & 75.00 & $6.00 \pm 0.316$ & $5.50 \pm 0.447$ \\
$5.0+2.0$ & $20-25$ & 70.00 & $4.00 \pm 0.316$ & $4.00 \pm 0.316$ \\
$5.0+2.5$ & $20-25$ & 70.00 & $3.00 \pm 0.273$ & $4.00 \pm 0.316$ \\
$6.0+0.5$ & $20-25$ & 30.00 & $3.00 \pm 0.273$ & $3.50 \pm 0.223$ \\
$6.0+1.0$ & $20-25$ & 40.00 & $4.00 \pm 0.316$ & $4.00 \pm 0.316$ \\
$6.0+1.5$ & $20-25$ & 50.00 & $3.00 \pm 0.273$ & $3.00 \pm 0.273$ \\
$6.0+2.0$ & $20-25$ & 65.00 & $3.00 \pm 0.273$ & $2.50 \pm 0.221$ \\
$6.0+2.5$ & $20-25$ & 50.00 & $3.00 \pm 0.273$ & $3.00 \pm 0.273$ \\
\hline
\end{tabular}


shoot formation obtained in MS media containing $5.0 \mathrm{mgL}^{-1}$ BAP with $1.5 \mathrm{mgL}^{-1}$ NAA (Table I, Plate-A) and followed by media containing $5.0 \mathrm{mgL}^{-1} \mathrm{BAP}$ with $2.0 \mathrm{mgL}^{-1} \mathrm{NAA}$ and $5.0 \mathrm{mgL}^{-1} \mathrm{BAP}$ with $2.5 \mathrm{mgL}^{-1} \mathrm{NAA}$. The lowest percentage of $(30 \%)$ of multiple shoot formation was observed in media having $6.0 \mathrm{mgL}^{-1} \mathrm{BAP}$ with $0.5 \mathrm{mgL}^{-1} \mathrm{NAA}$ with subculture. Highest mean number of shoots was $6.00 \pm 0.316$ in media having $5.0 \mathrm{mgL}^{-1}$ with $1.5 \mathrm{mgL}^{-1} \mathrm{NAA}$ and lowest mean number of shoot was $2.00 \pm 0.316$ in media containing $4.0 \mathrm{mgL}^{-}$

${ }^{1} \mathrm{BAP}$ with $2.0 \mathrm{mgL}^{-1} \mathrm{NAA}$. Average length of shoots gradually increased after induction of shoot. Length of shoots were recorded at four weeks of culture. Highest average length was recorded $5.50 \pm 0.447 \mathrm{~cm}$ in $5.0 \mathrm{mgL}^{-1}$ BAP with $1.5 \mathrm{mgL}^{-1} \mathrm{NAA}$ and followed by $4.50 \pm 0.316 \mathrm{~cm}$ in $4.0 \mathrm{mgL}^{-1}$ BAP with $2.5 \mathrm{mgL}^{-1} \mathrm{NAA}$ and $5.0 \mathrm{mgL}^{-1}$ BAP with $0.5 \mathrm{mgL}^{-1}$ NAA. Sai, et al, 2000 reported MS medium was the best medium for in vitro culture of $T$ flagelliforme. MS medium supplemented with $0.30 \mathrm{mgL}^{-1}(1.33 \mathrm{M}) \mathrm{BA}$ and 0.5 $\mathrm{mgL}^{-1}(2.46 \mathrm{M})$ indole-3 butyric acid (IBA). as the best medium for maximizing shoot number combined with normal complete plantlets from each bud were produced

\section{Callus induction}

In preliminary experiments it was observed that when the corm buds were placed horizontally on the media surface, the initiation of callus took place from both the cut ends. But when they were placed vertically callus took place only from the cut end dipped in the agar media. Horizontally oriented explants produced callus throughout their entire surface more rapidly than those which were placed vertically. Therefore corm buds explants were always placed horizontally on the agar surface to induce callus in all these experiments. It was further observe that IBA alone or in combinations with cytokinins (BAP, KIN) failed to initiate callus. Callus initiation occurred within 40 - 45days depending upon the concentration and combination of hormones. Frequency of callus formation ranged from 10 - $80 \%$ (Table II, Plate - B). Highest percentage ( $80 \%)$ of callus formation occurred in MS medium containing $0.5 \mathrm{mgL}^{-1}$ BAP with 2.0 $\mathrm{mgL}^{-1} \mathrm{NAA}$ followed by $75.00 \%$ in MS media supplementing with $0.5 \mathrm{mgL}^{-1} \mathrm{BAP}$ with $2.5 \mathrm{mgL}^{-1} \mathrm{NAA}$. The nature of calli were white, creamy white light green in colour and the

Table II: Effect of phytohormones on induction of calluses from corm bud explants of ghet kachu (Typhonium trilobatum Schott.)

\begin{tabular}{lcccccc}
\hline $\begin{array}{l}\text { Treatments } \\
\text { mg/l BAP+NAA }\end{array}$ & $\begin{array}{c}\text { Days to callus } \\
\text { initiation }\end{array}$ & $\begin{array}{c}\text { \% callus } \\
\text { formation }\end{array}$ & Callus colour & $\begin{array}{c}\text { Texture of } \\
\text { callus }\end{array}$ & $\begin{array}{c}\text { Fresh weight of } \\
\text { callus Mean } \pm \text { S.E }\end{array}$ & $\begin{array}{c}\text { Intensity of } \\
\text { callus growth }\end{array}$ \\
\hline $0.5+0.5$ & $40-45$ & 60.00 & W,LG & S,F & $6.00 \pm 0.223$ & profuse \\
$0.5+1.0$ & $40-45$ & 65.00 & LG & S,F & $7.00 \pm 0.316$ & profuse \\
$0.5+1.5$ & $40-45$ & 70.00 & LG & S,F & $7.00 \pm 0.316$ & profuse \\
$0.5+2.0$ & $40-45$ & 80.00 & WLG & S,F & $8.00 \pm 0.273$ & profuse \\
$0.5+2.5$ & $40-45$ & 75.00 & LG & S,F & $8.50 \pm 0.274$ & profuse \\
$1.0+0.5$ & $40-45$ & 20.00 & LG & S,F & $6.00 \pm 0.223$ & moderate \\
$1.0+1.0$ & $40-45$ & 30.00 & LG & S,F & $5.00 \pm .223$ & moderate \\
$1.0+1.5$ & $40-45$ & 30.00 & WLG & S,F & $4.50 \pm 0.223$ & moderate \\
$1.0+2.0$ & $40-45$ & 25.00 & WLG & S,F & $5.00 \pm 0.367$ & moderate \\
$1.0+2.5$ & $40-45$ & 20.00 & LG & S,F & $4.00 \pm 0.316$ & poor \\
$1.50+0.5$ & $40-45$ & 20.00 & WLG & S,F & $5.00 \pm 0.367$ & moderate \\
$1.50+1.0$ & $40-45$ & 30.00 & LG & S,F & $4.00 \pm 0.316$ & poor \\
$1.50+1.5$ & $40-45$ & 25.00 & LG & S,F & 4.000 .316 & poor \\
$1.50+2.0$ & $40-45$ & 20.00 & LG & S,F & $4.50 \pm 0.223$ & poor \\
$1.50+2.5$ & $40-45$ & 10.00 & LG & S,F & $4.00 \pm 0.223$ & poor \\
$2.0+0.5$ & $40-45$ & 20.00 & LG & S,F & $4.50 \pm 0.223$ & poor \\
$2.0+1.0$ & $40-45$ & 15.00 & LG & S,F & $4.00 \pm 0.223$ & poor \\
$2.0+1.5$ & $40-45$ & 20.00 & LG & S,F & $4.50 \pm 0.223$ & poor \\
$2.0+2.0$ & $40-45$ & 10.00 & LG & S,F & $3.50 \pm 0.223$ & poor \\
$2.0+2.5$ & $40-45$ & 10.00 & LG & S,F & $3.50 \pm 0.223$ & \\
\hline
\end{tabular}

" -"No. of root /shoot growth , "+" root/ shoot (1-3)/callus , LG =light Green ,W=White, S= Soft, F= Friable 
texture of calli were soft, friable and semi hard and compactness. The optimum callus growth in terms of fresh weight was $8.50 \pm 0.273 \mathrm{~g}$. in media having $0.5 \mathrm{mgL}^{-1} \mathrm{BAP}$ with $2.5 \mathrm{mgL}^{-1}$ NAA followed by $8.000 .273 \mathrm{~g}$ in media containing $0.5 \mathrm{mgL}^{-1}$ BAP with $2.0 \mathrm{mgL}^{-1} 1 \mathrm{NAA}$. Das, et al (1999) found optimum callus formation occur on semi solid Murashige and Skoog's medium supplemented with $0.25 \mathrm{mg}$ $\mathrm{L}^{-1}$ Kinetin and $3.0 \mathrm{mg} \mathrm{L}^{-1}$ NAA after six weeks of culture. Somatic embryogenesis was achieved by him upon transferring the callus to a medium containing $1.0 \mathrm{mgL}^{-1}$ kinetin and $0.25 \mathrm{mgL}^{-1} \mathrm{NAA}$.

\section{Shoot regeneration from callus}

In this experiment corm bud calli of Ghet kachu, Typhonium trilobatum were used to investigate the effect of different hormonal concentration and combinations. For shoot differentiation light green creamy colour compact calli were subcultured on MS medium supplemented with different concentrations and combinations of BAP and KIN alone and in combination with different concentration of NAA and IAA.
Morphogenic potentialities of cultured calli varied with hormonal treatments (Table III, plate-C). Calli sub cultured with different concentrations of IAA and NAA alone failed to differentiate any shoots. Calli produced shoots only when cultured IAA and NAA combined with Cytokinins. Highest percentage $85.00 \%$ of shoot regeneration was recorded in $5.0 \mathrm{mgL}^{-1} \mathrm{BAP}$ with $1.0 \mathrm{mg} \mathrm{L}^{-1} \mathrm{NAA}$ followed by $80 \%$ in media having $5.0 \mathrm{mgL}^{-1} \mathrm{BAP}$ with $0.5 \mathrm{mgL}^{-1} \mathrm{NAA}$. The lowest $10.00 \%$ of shoot regeneration was recorded in media containing $1.0 \mathrm{mgL}^{-1}$ BAP with $0.5 \mathrm{mgL}^{-1} \mathrm{NAA}$. The highest number of shoots per callus was recorded $11.00 \pm 0.447$ in media having $5.0 \mathrm{mgL}^{-1} \mathrm{BAP}$ with $1.00 \mathrm{mgL}^{-1} \mathrm{NAA}$. The lowest number of shoots per callus was recorded $4.00 \quad 0.316 \mathrm{~g}$. having most of the culture. Highest length of shoot $6.00 \pm$ 0.316 in media having $5.0 \mathrm{mgL}^{-1}$ BAP with $1.5 \mathrm{mgL}^{-1} \mathrm{NAA}$ and lowest length of shoots $3.00 \pm 0.273 \mathrm{~cm}$ in media having $1.0 \mathrm{mgL}^{-1} \mathrm{BAP}$ with $1.5 \mathrm{mg} \mathrm{L}^{-1} \mathrm{NAA}, 2.0 \mathrm{mgL}^{-1} \mathrm{BAP}$ with $1.0 \mathrm{mgL}^{-1} \mathrm{NAA}$ and $2.0 \mathrm{mgL}^{-1} \mathrm{BAP}$ with $2.0 \mathrm{mgL}^{-1} \mathrm{NAA}$.

Table III: Effect of phytohormones on regeneration of calluses from corm bud explants of ghet kachu (Typhonium trilobatum Schott )

\begin{tabular}{|c|c|c|c|c|c|c|c|c|c|c|}
\hline \multirow{3}{*}{$\begin{array}{l}\text { Treatments } \\
\text { mg/l } \\
\text { BAP+NAA }\end{array}$} & \multirow{3}{*}{$\begin{array}{l}\text { Days to } \\
\text { callus }\end{array}$} & \multirow{3}{*}{\multicolumn{2}{|c|}{$\begin{array}{l}\text { \%callus Callus } \\
\text { regene- colour } \\
\text { ration }\end{array}$}} & \multirow{3}{*}{$\begin{array}{l}\text { Texture } \\
\text { of } \\
\text { callus }\end{array}$} & \multirow{3}{*}{$\begin{array}{l}\text { Fresh weight } \\
\text { of callus } \\
\text { with shoot } \\
\text { Mean+S.E }\end{array}$} & \multicolumn{2}{|c|}{ Organogenic response } & \multirow{3}{*}{$\begin{array}{c}\text { Intensity } \\
\text { of } \\
\text { callus }\end{array}$} & \multirow{3}{*}{$\begin{array}{c}\begin{array}{c}\text { Average no. } \\
\text { of shoot } \\
\text { per culture }\end{array} \\
\text { Mean+S.E }\end{array}$} & \multirow{2}{*}{$\begin{array}{l}\text { Average } \\
\text { length of } \\
\text { shoot per }\end{array}$} \\
\hline & & & & & & Root & Shoot & & & \\
\hline & & & & & & & & & & Mean+S.E \\
\hline $1.0+0.5$ & $12-18$ & 10.00 & $\mathrm{Cr}$ & $\mathrm{CH}$ & $3.00 \pm 0.273$ & & & poor & 0.316 & 0.316 \\
\hline & & 20.00 & $\mathrm{Cr}$ & $\mathrm{CH}$ & & & & poor & $4.50 \pm 0.316$ & \\
\hline $1.0+1.5$ & $12-18$ & 30.00 & $\mathrm{Cr}$ & $\mathrm{CH}$ & $4.00 \pm$ & & & poor & $5.00 \pm 0.273$ & 3.00 \\
\hline $1.0+$ & & 35.00 & $\mathrm{Cr}$ & $\mathrm{CH}$ & & & & & & \\
\hline $1.0+2$ & & 30.00 & $\mathrm{Cr}$ & $\mathrm{CH}$ & & & & poor & $4.00 \pm 0.316$ & \\
\hline $2.0+0.5$ & $12-18$ & 25.00 & $\mathrm{Cr}$ & $\mathrm{CH}$ & 4.50 & pov & pos & poor & 316 & 4.00 \\
\hline & & & $\mathrm{Cr}$ & & & & & & & \\
\hline $2.0+1$ & & 40.00 & $\mathrm{Cr}$ & $\mathrm{CH}$ & & & & moderate & & \\
\hline $2.0+2$ & & 30.00 & $\mathrm{Cr}$ & $\mathrm{CH}$ & & & & poor & & \\
\hline $2.0+2.5$ & $12-18$ & 20.00 & $\mathrm{Cr}$ & $\mathrm{CH}$ & $5.00 \pm 0.273$ & moderate & moderate & poor & $4.00 \pm 0$ & $3.50 \pm 0.273$ \\
\hline $3.0+$ & & & $\mathrm{Cr}$ & $\mathrm{C}$ & & & & hode & & \\
\hline $3.0+1$ & & 45.00 & $\mathrm{Cr}$ & $\mathrm{CH}$ & & & moderate & mode & 316 & \\
\hline $3.0+1.5$ & & 40.00 & $\mathrm{Cr}$ & $\mathrm{CH}$ & $8.00 \pm 0.273$ & + & + & moderate & $5.00 \pm 0.273$ & $4.00 \pm 0.316$ \\
\hline $3.0+2.0$ & $12-18$ & 35.00 & $\mathrm{Cr}$ & $\mathrm{CH}$ & $7.50 \pm 0.316$ & + & + & poor & $4.00 \pm 0.316$ & $3.50 \pm 0.273$ \\
\hline $5.00+$ & & 80.00 & $\mathrm{Cr}$ & $\mathrm{CH}$ & & & & ase & & \\
\hline $5.00+1.0$ & & 85.00 & $\mathrm{Cr}$ & $\mathrm{CH}$ & & & & profuse & $11.00 \pm 0.447$ & $5.50 \pm 0.447$ \\
\hline $5.00+1.5$ & $12-18$ & 70.00 & $\mathrm{Cr}$ & $\mathrm{CH}$ & $11.00 \pm 0.447$ & good & good & profuse & $10.00 \pm 0.833$ & $6.00 \pm 0.316$ \\
\hline $5.00+2.0$ & $12-18$ & 65.00 & $\mathrm{Cr}$ & $\mathrm{CH}$ & $10.00 \pm 0.833$ & good & good & profuse & $10.00 \pm 0.833$ & $5.00 \pm 0.273$ \\
\hline
\end{tabular}

" - "No. of root /shoot growth, "+" root/ shoot (1-3)/callus, $\mathrm{Cr}=$ Creamy colour, W=Whitish, $\mathrm{C}=\mathrm{Compact}, \mathrm{H}=\mathrm{Hardiness}$. 


\section{Rootings}

In vitro grown plantlets usually induce roots in proliferation medium. So, the regenerated shoot from explants was needed to induce roots for their ultimate establishment in the field from the time of establishment of explants to attain length suitable $(4-5 \mathrm{~cm})$ for rooting proliferated shoots obtained from various explants took 4-8 weeks. Therefore experiments for rooting were conducted only after this period. In most instances emergence of roots in auxins and cytokinins supplemented medium started within 7-10days of culture and continued to grow up to the end of fourth week. Micro cuttings which failed to form roots in this period were unable to produce roots even after 6 weeks of culture (Table IV, plate- D). Among the auxins employed IAA was found to be the more effective in the induction of roots without inducing callus.

\section{Acclimatization}

Through washing and differentiating from agar medium callus derived plantlets were planted and hardened in growth chamber in plastic pot with fertile loamy soil for observing better performance of acclimatization. Hundred percentage plantlets were survived well with good vegetative growth.

\section{Acknowledgment}

The First author wishes to express his gratitude to the University Grants commission, Dhaka -1207, Bangladesh for nominating as the $\mathrm{Ph}$. D fellow regarding this research work.

Table IV: Effect of different concentration of auxin on root induction regenerated plants of Ghetkachu

\begin{tabular}{lcccc}
\hline Growth regulators $\mathrm{mgl}^{-1}$ & $\begin{array}{c}\text { Days to root } \\
\text { proliferation }\end{array}$ & $\begin{array}{c}\text { \% of root } \\
\text { proliferation }\end{array}$ & $\begin{array}{c}\text { No. of root per plant } \\
\text { Mean+S.E }\end{array}$ & $\begin{array}{c}\text { Root length (in } \mathrm{cm} \text { ) } \\
\text { Mean } \pm \text { S.E }\end{array}$ \\
\hline IBA-0.4 & $07-10$ & 20.00 & $2.00 \pm .316$ & $2.50 \pm 0.316$ \\
IBA-0.5 & $07-10$ & 15.00 & $3.00 \pm 0.273$ & $2.50 \pm 0.316$ \\
IBA-0.6 & $07-10$ & 10.00 & $2.00 \pm 0.316$ & $2.00 \pm 0.316$ \\
IAA-0.2 & $07-10$ & 40.00 & $4.00 \pm 0.316$ & $2.50 \pm 0.316$ \\
IAA-0.3 & $07-10$ & 50.00 & $5.00 \pm 0.273$ & $3.00 \pm 0.273$ \\
IAA-0..4 & $07-10$ & 60.00 & $5.00 \pm 0.273$ & $3.00 \pm 0.273$ \\
IAA-0.5 & $07-10$ & 45.00 & $6.00 \pm 0.316$ & $3.00 \pm 0.273$ \\
IAA-0.6 & $07-10$ & 45.00 & $6.00 \pm 0.316$ & $4.00 \pm 0.316$ \\
\hline
\end{tabular}

$-=$ not response
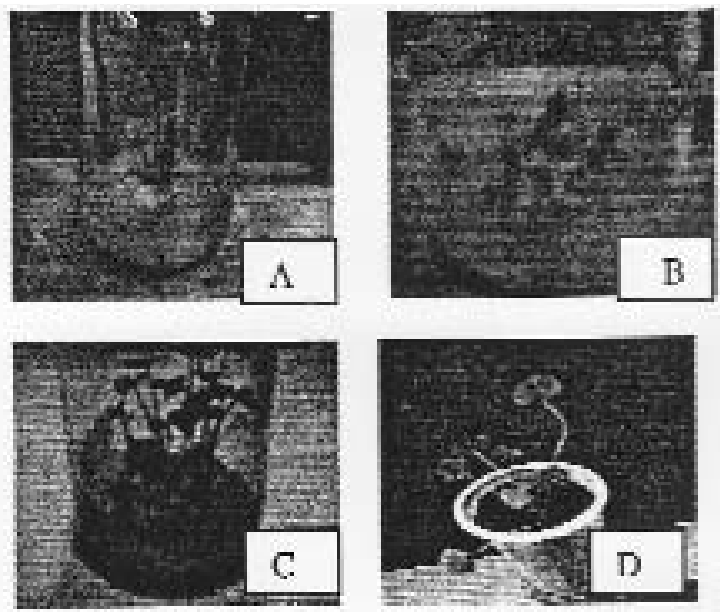

Fig: A. Multiple shoot regeneration after 30days B. Callus formation after 50days. C. Callus regeneration after 30 days. D. Acclimatization of Ghet kachu after two months observation.

\section{References}

Das P, Palai SK, Patra A, Samantaray S and Rout GR 1999. In vtiro somatic embryogenesis in Typhonium trilobatum Schott. Plant Growth regulation. 27(3): 193-197.

Ghani A 1998. Medicinal plants of Bangladesh with chemical constituents and uses. Second edition. Asiatic Society of Bangladesh, Dhaka .p-418.

Hay A 1993. The genus Typhonium (Araceae-Areae) in Australasia. Blumea 37: 345-376.

Hetterscheid WLA and Boyce PC 2000. A reclassification of Sauromatum schott and new species of Typhonium Schott (Araceae). Aroideana 23: 48-55. 
Hetterscheid WLA, Sookchaloem D and Murata J 2001. Typhonium (Araceae) of Thailand : new species and a revised key . Aroideana 24: 30-35.

Kritikar KR and Basu BD1914. Ind. Med. P1.t-998 Journ. \& Proc.Asiat.Soc.Bengal, New ser.x.t32 .

Murashige T and Skoog F 1962. A revised medium for rapid growth and bioassays with tobacco tissue cultures Physiologia Plantarum 15: 473- 491.

Nicolson DH and Sivadasan M 1981. Four frequently confused species of Typhonium Schott (Araceae). Blumea 27: 483-497.

Rout GR 2006. Evaluation of genetic evaluationship in Typhonium species through random amplified polymorphic DNA markers. Biologia Plantarum 50(1): 127-130.

Sookchaloem D 1995. Typhonium (Araceae) in Thailand. Thai For. Bull. (Bot) 23: 18-39.
Sriboonma D, Murata J and Iwatsuki L 1994. A revision of Typhonium (Araceae). J Fac. Sci. Univ. Tokyo III 15: 255-313 .

Sai ST, Keng CL, Pargini $\mathrm{N}$ and Teo $\mathrm{CKH}$ 2000. In vitro propagation of Typhonium flagelliforme (lodd) Blume. 36(5): 402-406

Vattarchya S 1405 Beng. Chirongib Banoshadi .Ananda publishers Private limited .Calcutta-9.ix part .p 178-181.

Wang JC andYang KC 1996. The Genus Typhonium (Araceae) in Taiwan -Bot. Bull. Acad. Sin 37:159-163.

Whitkus R, Doebley J and Wendel F 1994. Nuclear DNA markers in Systematics and Evolution - In L Philips, I K Vasil (ed): DNA- based markers in plants pp 116141. Kluwer Acad. Publ. Dordrecht.

Manuscript received on 25 January 2011; revised on 22 May 2011; accepted on 01 November 2011. 